\title{
Environmental exposure to xenoestrogens and oestrogen related cancers: reproductive system, breast, lung, kidney, pancreas, and brain
}

\author{
Aleksandra Fucic ${ }^{*}$, Marija Gamulin², Zeljko Ferencic ${ }^{3}$, Jelena Katic ${ }^{1}$, Martin Krayer von Krauss ${ }^{4}$, Alena Bartonova ${ }^{5}$, \\ Domenico F Merlo ${ }^{6}$
}

From HENVINET (Health and Environment Network) final conference

Brussels, Belgium. 14 May 2010 - 15 May 2010

\begin{abstract}
The role of steroids in carcinogenesis has become a major concern in environmental protection, biomonitoring, and clinical research. Although historically oestrogen has been related to development of reproductive system, research over the last decade has confirmed its crucial role in the development and homeostasis of other organ systems. As a number of anthropogenic agents are xenoestrogens, environmental health research has focused on oestrogen receptor level disturbances and of aromatase polymorphisms. Oestrogen and xenoestrogens mediate critical points in carcinogenesis by binding to oestrogen receptors, whose distribution is age-, gender-, and tissuespecific. This review brings data about cancer types whose eatiology may be found in environmental exposure to xenoestrogens. Cancer types that have been well documented in literature to be related with environmental exposure include the reproductive system, breast, lung, kidney, pancreas, and brain. The results of our data mining show (a) a significant correlation between exposure to xenoestrogens and increased, gender-related, cancer risk and (b) a need to re-evaluate agents so far defined as endocrine disruptors, as they are also key molecules in carcinogenesis. This revision may be used to further research of cancer aetiology and to improvement of related legislation. Investigation of cancers caused by xenoestrogens may elucidate yet unknown mechanisms also valuable for oncology and the development of new therapies.
\end{abstract}

\section{Background}

Despite the considerable efforts to decrease environmental pollution we still witness uncontrolled introduction of new compounds in living and working environment. Additionally, pollution control in low income and developing countries has seen limited success. The balance between needs of a fast growing human population and technology/science development is questionable, partially as a consequence that the available knowledge is not always applied in an efficient way as it should be.

The last century's paradigm "one agent - one disease" has helped to identify the major causal pathways and the identification of pollution related diseases, including

\footnotetext{
* Correspondence: afucic@imi.hr

'Institute for Medical Research and Occupational Health, Zagreb, Ksaverska c 2, Croatia

Full list of author information is available at the end of the article
}

cancer. Based on this approach, epidemiological studies set off many activities to reduce pollution and prevent exposure. However, a large body of data accumulated over the last decade, with a recent significant contribution of molecular biology, clearly shows that this historical simplistic interpretation of biomonitoring data fails to answer a number of questions about environmental threats to human health.

Cancer incidence monitoring in developed countries is relatively accurate. A better classification of cancer types, the networking of cancer registries, and the increasing population coverage for cancer registration are unfortunately accompanied, due to unsolved technical and organizational difficulties, by publishing of cancer register reports with a lag of several years. This lag is a serious obstacle in identifying current environmental health risks and setting timely effective preventive measures. 
According to recent data [1], childhood cancer incidence increases $1 \%$ a year all over Europe. In the adult population a rising trend is reported for soft tissue sarcoma, brain tumours, germ-cell tumours, lymphomas, renal cancers, leukemias, breast cancer, and lung cancer in women. Breast, colorectal, prostate, and lung cancer are the most commonly diagnosed cancers in the European population [2]. Only limited part of the detected increase may be related to screening programs.

During the last decade, environmental health and oncology have shown an increasing interest in oestrogen as an evolutionary conserved molecule. With its endocrine, paracrine, and neurotransmitting activity [3-5], oestrogen is not limited to the development and regulation of the reproductive system. The distribution of oestrogen receptors in mammalian tissues suggests that oestrogens could have a significant role in orchestrating a number of pathways in living organisms during development and adulthood. Additionally, new evidences confirm a strong impact of this molecule on carcinogenesis [6-9].

Very little is known about changes in oestrogen levels and the tissue ratio between alpha and beta oestrogen receptors (ER) during development [10]. In the second trimester of human foetal development the highest concentrations of ER beta mRNA are found in the testis and the ovary and of ER alpha mRNA in the uterus. Relatively high concentrations of either receptor are also present in the spleen, while low levels are detected in the kidney, thymus, skin, and lung [11]. The pre-pubertal ratio between ERs alpha and beta in human tissues in males and females is not known. Additionally, ER alpha and beta are polymorphically distributed and as such they play different roles in carcinogenesis [12-14].

At higher levels, oestrogen is carcinogenic [15]; similar to ionizing radiation it may produce reactive oxygen species and cause hypomethylation and microsatellite instability $[9,16-18]$. Its metabolites, quinones, cause the formation of DNA adducts, depurination, lipid-derived aldehyde-DNA adducts, and aneuploidy $[15,19]$. By decreasing glutathione-S-transferases, oestrogens may increase cellular oxidative DNA damage in oestrogenresponsive tissues, when the organism is simultaneously exposed to genotoxicants. This is an early step in the process of carcinogenesis [20].

Gender differences in the incidence of cancers such as the lung, kidney, or pancreas cancer suggest that hormones may play a role in their aetiology [21]. Recent findings suggest that all neoplastic mammalian tissues are characterized by disturbances in ER levels [6]. As gender related estrogen levels in foetal, and prepubertal tissues, the tissue specific ER distribution and oestrogen bimodal activity modulate the development of biological pathways and organogenesis $[22,23]$ some cancer types may have origin in their prenatal and postnatal disturbance caused by exposure to xenoestrogens.

The general population is exposed to a number of hormonally active compounds on a daily basis. These compounds were introduced in the living environment during the last few decades, the majority of which are xenoestrogens. Chemicals like polycyclic aromatic hydrocarbons (PAH), pesticides, polychlorinated biphenyl (PCB), dichlorodiphenyl-trichlorethane (DDT), some drugs (e.g., antiepileptic drugs), fungicides, cotinine, phytoestrogens, mycotoxins, bisphenol A (a plastics additive), phthalates, alkylphenols, and metalloestrogens mimic oestrogen action, affect oestrogen levels, or bind to oestrogen receptors [24-29]. Xenoestrogens are present in a number of substrates such as cigarette smoke, automobile exhaust, chemical industry pollutants, grilled meat, volcano dust, forest fire smoke, milk, water, and cosmetic products. This means that all human population may be exposed to them.

This article seeks to give an insight in how environmental exposure to xenoestrogens relates to breast, lung, kidney, brain, pancreas, and reproductive system cancers, which are all characterized by disturbances in ER.

\section{Breast cancer}

The reports on decrease of breast cancer incidence in women 50-69 years old are related to improvement of preventive measurements such as mammography screening in developed countries. In the United States, Australia, and Western Europe this decrease seems to follow a decrease in hormonal therapy [30], as oestrogen plays important role in pathogenesis of breast cancer $[31,32]$.

Factors involved in the development of breast cancer incidence include the socioeconomic status, some food additives, pesticides, oestrogen and progesterone replacement therapy, some antibiotics, radiation, mutations at genes BRCA1, BRCA2, metabolizing enzyme polymorphisms, epidermal growth factor and its receptor (HER), androgen levels, and insulin-like growth factor [33-35]. Age (including transplacental, prepubertal) may also play an important role in oestrogen exposure-related breast cancer risk that probably involves epigenetic mechanisms [36-39].

Currently there are some 160 xenoestrogens that may be involved in breast cancer development [40-42]. Women are the largest consumers of cosmetic products which may be a significant source of xenoestrogens. Some, such as metalloestrogens (e.g., aluminium salts), parabens, cyclosiloxanes, triclosan, UV screeners, phthalates, Aloe Vera extracts, and musk are present in numerous cosmetics products. Humans are exposed to these chemicals transcutaneously and measurable levels have been detected in human breast tissue [23]. 
Alcohol is also related with increased risk of breast cancer development as even low alcohol consumption increases serum oestradiol (especially for carriers of a certain alcohol dehydrogenase allele) and stimulates ER alpha $[43,44]$. On animal model it is shown that alcohol increases oestradiol levels in dams, which leads to higher levels of ER alpha receptors in their offspring mammary gland and may launch tumorigenesis [37].

The effect of diet on breast cancer development was observed in Japanese women after the Second World War when dramatic changes in their diet happened such as increased consumption of meat, eggs, and milk containing oestrogens or oestrogen-like compounds [45]. Milk is a source of oestrogen due to the practice of milking pregnant cows [46].

Heterocyclic amine and their metabolites, especially 2amino-1-methyl6-phenylimidazo (4,5-b) pyridine ( $\mathrm{PhIP})$ is present in high concentrations in well-cooked meat and it binds to and activates the breast cell ER alpha $[47,48]$. In animal model, it causes breast cancers [49]. The suggested mechanisms of PhIP mechanisms are formation of PhIPDNA adducts and increase of proliferation in mammary gland terminals and buds [50]. Similarly, at concentrations higher than $140 \mu \mathrm{g} / \mathrm{m} 3$ polyaromatic hydrocarbons from food may increase breast cancer risk in postmenopausal women if they were exposed to it early in life [51].

Styrene, a widely used plastic for food packing, has been associated with breast cancer risk both in men and women [52]. Direct intake of styrene is via food packed or even cooked in styrene boxes with a direct migration of styrene to food. Styrene and its metabolites bind to ER alpha [53], cross the placental barrier, and also affect the development of reproductive organs [54,55].

The carcinogenic potential of xenoestrogens may also depend on polymorphism of metabolic enzymes. It is shown that subpopulation carrying a polymorphism of metabolic enzyme CYP1A1 $\mathrm{m} 2$ is more susceptible to breast cancer development after exposure to polychlorinated biphenyls (PCB), which may explain contradictory epidemiological reports on the association between breast cancer incidence and PCB exposure [35,56,57].

\section{Lung cancer}

Lung cancer is the predominant cause of cancer mortality [58]).There is a gender difference in the incidence of lung cancer types. The leading cause in men is the squamous cell carcinoma, and in women adenocarcinoma. Oestrogen and ER distribution could be the main cause of this difference $[59,60]$. Despite the fact that lung cancer incidence is increasing in women [61-64] studies reporting lung cancer incidence basically rarely give attention to possibly gender related susceptibility [65-67]. Lung cancer is about 70\% ER beta positive. The ratio between ER alpha and ER beta in the lung tissue seems to be relevant for lung cancer development and may explain the higher incidence of lung adenocarcinoma in women than in men [68]. Increased lung cancer risk in women is associated with a lower social status and high level of indoor pollution with PCBs during cooking as a consequence of coal usage [69,70]. ER beta levels in lung cancer are gender related and have impact on survival rate [71]. While ER beta receptor positive or negative lung cancers has no impact on survival in women, in men ER beta positive lung cancer is associated with a significantly lower mortality than ER beta negative lung cancer [72]. ER alpha modulates lung differentiation and maturation while ER -beta causes proliferation of lung cancer cells [73,74]. Gender specific distribution of CYP19 (aromatase) in lung cells puts in correlation oestrogen levels and lung cancer etiology [75]. Additionally, women taking oestrogen therapy have shown increased lung cancer incidence [76]. Same as for breast cancer epidermal growth factor and its receptor HER plays a significant role in non-small cell carcinoma and is associated with endogenous estrogen exposure [77].

Smoking remains the major cause of lung cancer in humans [78]. Methylnitrosamino-pyridyl-butanone, a powerful carcinogenic agent contained in cigarette smoke is ER beta receptor related [69]. The activity of nicotine is gender-specific [79], since cotinine, a nicotine metabolite, is an aromatase inhibitor [80] that decreases oestrogen end increases testosterone levels. Polonium 210 in cigarettes [81] may have similar activity as other metalloestrogens $[24,82]$. Other carcinogens in cigarette smoke should be re-evaluated for their xenoestrogen or aromatase inhibitor potency.

Traffic air pollution is also related to lung cancer $[83,84]$. A number of compounds from traffic emissions are oestrogen ligand active compounds [85]. PAHs represent one of the major mixtures of agents that are present in polluted air have been demonstrated to affect oestrogen homeostasis [86-88].

Industrial emissions also contain pollutants with oestrogen-like activity, such as heavy metals and dioxins [89]. A significant association between industrial air pollutants and lung cancer risk has been reported in women [90].

Arsenic is a known lung carcinogen [6] whose biological effects include increased ER alpha transcription. In animals, transplacental exposure to arsenic causes lung cancer in female offspring. This suggests that arsenic can modify genes during foetal development which may cause lung cancer later in life [91]. Figure 1 shows complex environmental exposures which may lead to the lung carcinogenesis.

\section{Kidney cancer}

Data on the environmental aetiology of kidney cancer are not available, and much more research is needed. The fact that renal cell carcinoma, the most common 


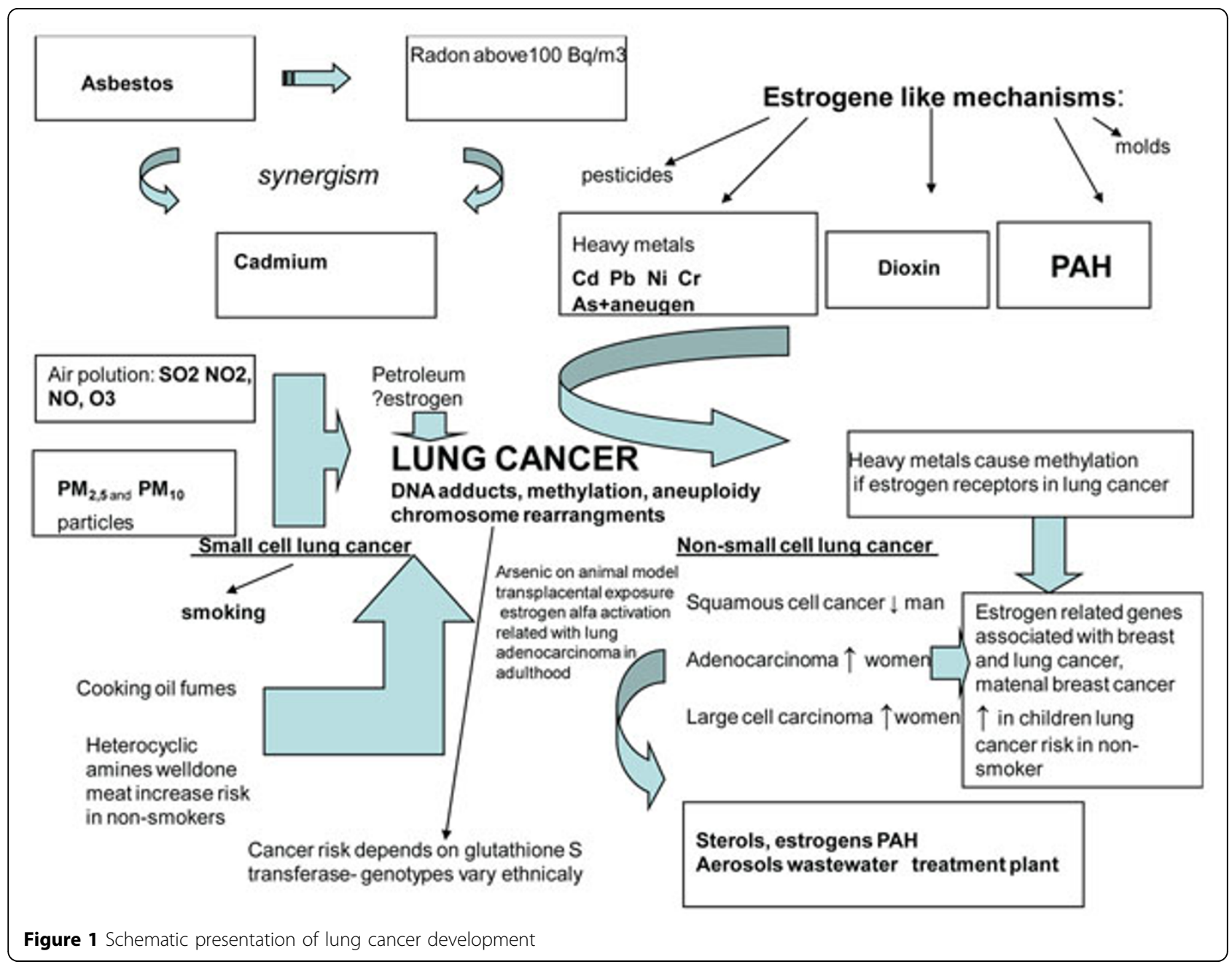

type of kidney cancer, can be induced by exposure to oestrogens [92] in animal model suggests the involvement of oestrogen receptors in the aetiology of kidney cancer and of a possible role of xenoestrogens. Kidney cancer incidence seems to be gender -related, with an incidence that is two times higher in men than in women [93]. In addition, genetic polymorphisms of ER alpha in the kidney seem to play a significant role in the development of kidney cancer [92]. Cadmium and arsenic as xenoestrogens may also induce kidney cancer $[94,95]$

\section{Pancreatic cancer}

Understanding of pancreatic cancer aetiology is crucial, as it is the fourth leading cause of cancer deaths in the USA [64] and one of the most aggressive diseases. The incidence of pancreatic cancer has been relatively stable worldwide over the last few decades [96-98]. It is more frequent in men than in women $[99,100]$. Pancreatic cancer cells are ER alpha and beta positive and consequently may be modulated by oestrogen [101] which is consistent with similar mechanisms observed in xenoestrogenrelated cancers $[102,103]$. There are very few data on the effects of xenoestrogens on pancreatic cancer incidence.

Methylnitrosamino-pyridyl-butanone is the only compound demonstrated to cause pancreatic cancer in animal models [104]. This finding has also been reported for the adenocarcinoma of the lung and has been related to ER beta activation [68].

It is also known that consumers of fried meat run a higher risk of pancreatic cancer development probably due to exposure to benzo(a)pyrene and other food contaminants that have xenoestrogenic properties $[45,105]$.

\section{Brain tumour}

Brain tumours are characterized by disturbances in ERs [106-108]. Transplacental exposure to xenoestrogens may increase the risk of brain tumour development $[79,80]$. Xenobiotics that inhibit aromatase also inhibit the conversion of oestrogen to testosterone and may have a significant impact on brain pathology, given the evidence that disturbed levels of testosterone have impact 
on apoptosis and intracellular signaling [109] Increased brain cancer incidence has been reported in humans living near petrochemical industries [110]. Despite the fact that the exact chemical composition of the mixture of air pollutants remains unknown, polycyclic aromatic hydrocarbons (PAH) are present in polluted air in such areas [67]. PAHs as xenoestrogen-like agents [87] may have played a causal role on the excess of brain cancer incidence detected

\section{Reproductive system}

Testicular cancer incidence has significantly increased over the last few decades with yet no clear hypothesis on impact of environment on its aetiology [111]. As this trend cannot be explained by cryptorchidism, smoking, genetic variations, or physiological stress, the role of environmental exposure is being investigated to elucidate its aetiology and to identify preventive measures [112].

Both ER alpha and beta are expressed in the human testis and are involved in the control of testicular function [113]. The role played by xenoestrogens on testis development is still only partly known in the animal model, with results showing very dynamic changes in tissue sensitivity to xenoestrogens with unknown consequences during puberty and adulthood [114].

There are a limited number of studies reporting possible association between testicular cancer and disturbances in oestrogen levels. Testicular cancer has been reported in sons of smoking mothers [115], but also in mothers who were taking antiepileptics during pregnancy [116]. Both antiepileptics and cotinine from cigarette smoke are aromatase inhibitors. Transplacental exposure to aromatase inhibitors and consequently increased levels of testosterone may have long-term effects in humans, as shown in an animal model [117].

Epidemiological studies also suggest increased risk of testicular cancer following prenatal exposure to oestrogens [118].

Styrene storage containers may contaminate food which becomes a source of styrene exposure. Transplacental exposure to low levels of styrene may lead to the disturbed development of male genital organ [54]. However, its effect on cancer development remains unknown.

Endocrine disrupting chemicals which disturb ERs can cause female reproductive dysfunction $[119,120]$. As ovarian cancer therapy is still not marked with significant success and mortality is very high it is of major significance elucidation of its aetiology [121].

Cadmium, one of most investigated heavy metals, has a significant role on ovarian and reproductive functions, as it lowers progesterone levels and mimics oestrogen in various tissues by binding to ER alpha. Cadmium is not confined to occupational exposure alone; it is found in cigarette smoke, food, nickel/cadmium batteries, pigments, and plastics [122].

Ovarian cancer is associated with milk and cheese consumption due to oestrogen and insulin growth factor present in milk of pregnant cows $[46,123]$.

According to recent experimental evidence, uranium in water should be further considered in research as an additional risk for reproductive cancers [82].

\section{Conclusions}

As an evolutionary conserved molecule, oestrogen is present in both plants and animals. Oestrogen is recognized today as a critical modulator of development, homeostasis in adulthood and orchestration of response to environment.

Although gene polymorphisms can change cancer incidence $[124,125]$, it is clear that environment has predominance over genes in cancer risk. Responses to environmental stressors are age- and gender related, and transplacental exposure to xenoestrogens has been shown to have long-term effects in experimental models, as it modulates hormonal response in puberty This means that exposure to endocrine agents not only poses a health risk during exposure, but also increases susceptibility later in life $[114,126,127]$. Differences in susceptibility to xenoestrogens may be related to steroid and xenobiotic receptor levels, which are high in young adults (15-38y old) and decrease with age [128].

Current estimates of cancer risk in humans do not account properly for transplacental and environmental (including occupational) exposure to xenoestrogens. The role of xenoestrogens in cancer development should be re-evaluated using a new approach that would reflect the complexity of carcinogenesis.

Reductionism as the main scientific philosophy of the $20^{\text {th }}$ century gave a significant input to environmental health. However, the quantity of data available in noosphere, systems biology as a tool and new softwares for data sharing enable the investigation of interactions between xenoestrogens and other environmental stressors, such as radiation, and add new dimensions to the research of cancer aetiology using complexity as a new scientific philosophy. Contemporary mathematical models and systems biology allows the incorporation of all available data and modeling cancer risk allowing free interaction and clustering of data.

The collaboration of environmental health with oncology would be of crucial significance in the study of xenoestrogens as estrogen has today significant position in oncological diagnostics and therapy what includes measurements of ER levels in different tissues. Clinical oncology today takes part in scientific projects in order to achieve optimal treatment at the individual level (tailored therapy) and produces large amounts of data that reflect a 
tight gene-environment interaction and point to age and gender specific susceptibility. Collaboration between pharmacokineticians, oncologists, histopathologists, molecular epidemiologists, and genotoxicologists may improve our knowledge of cancer aetiology and lead to gender specific and final individualized therapies.

Available information systems and building of integrated exposure-disease pathways will give policymakers much more useful input in future for more efficient regulations than a large number of agent- and disease-specific studies.

\section{Acknowledgments}

This work was supported by the EU project HENVINET 6th Framework Programme, Coordination Action (Contract no. GOCE-CT-2006-037019), http://www.henvinet.eu.

This article has been published as part of Environmental Health Volume 11 Supplement 1, 2012: Approaching complexities in health and environment. The full contents of the supplement are available online at http://www. ehjournal.net/supplements/11/S1.

\section{Author details}

${ }^{1}$ Institute for Medical Research and Occupational Health, Zagreb, Ksaverska c 2, Croatia. 'University Hospital "Zagreb", Zagreb, Kispaticeva 12, Croatia. ${ }^{3}$ Children's Hospital "Srebrnjak", Zagreb, Srebrnjak 100, Croatia. "WHO, Regional Office for Europe, Copenhagen, Scherfigsvej 8, Denmark. ${ }^{5}$ NILU Norwegian Institute for Air Research, Kjeller, Norway. ${ }^{6}$ National Institute for Cancer Research, Genoa, Largo R. Benzi 10, Italy.

\section{Authors' contributions}

AF gave the basic idea/hypothesis and drafted the manuscript. MG, ZF and JK participated in its design and helped to draft the manuscript. MAK and $A B$ gave significant contribution in modelling of approach of data interpretation. DFM drafted the manuscript and gave significant contribution in interpretation of collected data. All authors read and approved the final manuscript.

\section{Competing interests}

There is no competing interest in interpretation of data or presentation of information in this article which may be influenced by personal or financial relationship with other people or organizations.

\section{Published: 28 June 2012}

\section{References}

1. Pritchard-Jones K, Kaatsch P, Steliarova-Foucher E, Stiller CA Coebergh JWW: Cancer in children and adolescence in Europe: developments over 20 years and future challenges. European $J$ Cancer 2006, 42:2183-2190.

2. Ferlay J, Autier P, Boniol M, Heaune M, Colombet M, Boyle P: Estimates of the incidence and mortality in Europe in 2. Annals of Oncology 2007, 18:581-592.

3. Moss RL, Gu O, Wong M: Estrogen: nontranscriptional signaling pathway. Recent Prog Horm Res 1997, 52:33-68.

4. Wooley CS: Acute effects of estrogen on neuronal physiology. Ann RevPharmacol Toxicol 2007, 47:657-80.

5. Fucic A, Miškov S, Zeljezic D, Bogdanovic N, Katic J, Gjergja R, Karelson E, Gamulin M: Is the role of estrogens and estrogen receptors in epilepsy still underestimated? Medical Hypotheses 2009, 73:703-705.

6. Chen GC, Zeng Q, Tse GMK: Estrogen and its receptors in cancer. Med Res Review 2008, 28(6):954-974

7. Gonzales RJ, Ansar S, Duckles SP, Krause DN: Androgenic/estrogenic balance in the male rat cerebral circulation: metabolic enzymes and sex steroid receptors. J Cereb Blood Flow Metab 2007, 27(11):1841-1852.

8. Lemmen JG, Arends RJ, van Boxtel AL, van der Saag PT, van der Burg B: Tissue and time dependent estrogen receptor activation in estrogen reporter mice. J Mol Endocrinol 2004, 32:689-701.
9. Roy D, Liehr JG: Estrogen DNA damage and mutations. Mutat Res 1999, 424:107-115.

10. Knapczyk K, Duda M, Szafranska B, Wolsza K, Panasiewicz G, Koziorowski M, Slomczynska M: Immunolocaliosation of oestrogen receptors alpha (Eralpha) and beta (Erbeta) in porcine embryos and fetuses at different stages of gestation. Acta Vet Hung 2008, 56(2):221-233.

11. Branderberger AW, Tee MK, Lee JY, Chao V, Jaffe RB: Tissue distribution of estrogen receptors alpha (Er?) and beta $(\operatorname{Er} \beta)$ mRNA in the midgestational human fetus. J Clin Endocrinol \& Metabolism 1997, 82(10):3509-3512.

12. Paruthiyil S, Parmar $H$, Kerekatte V, Cunha GR, Firestone GL, Leitman DC: Estrogen receptor beta inhibits human breast cancer cell proliferation and tumor formation by causing a G2 cell cycle arrest. Cancer Res 2004, 64(1):423-428.

13. Grabinski JL, Chisholm G, Smith LS, Drengler RL, Kalter S, Rodriguez G, Garner A, Cooper J, Pollock B, Kuhn J: ER alpha genotypes and breast cancer. J Clin Oncol 2008, 26(15S):501.

14. Hall JM, Korach KS: Analysis of the molecular mechanisms of human estrogen receptors alpha and beta reveals differential specificity in taret promotor regulation by xenoestrogens. J Biol Chem 2002, 277(46):44455-44461

15. Cavalieri EL, Stack DE, Devanesan PD: Molecular origin of cancer: catechol estrogen-3,4-quinones as endogenous tumor initiators. Proc Nat Acad Sci USA 1997, 94:10937-10942.

16. Roy D, Cai Q, Felty Q, Narayan S: Estrogen-induced generation of reactive oxygen and nitrogen species, gene damage and estrogen dependent cancers. J Toxicol Environ Health, Part B 2007, 10(4):235-257.

17. Dubrova YE, Ploshchanskaya OG, Kozionova OS, Akleyev AV: Minisatellite germline mutation rate in the Techa River population. Mutat Res 2006, 602(1-2):74-82

18. Kaup S, Grandjean V, Mukherjee R, Kapoor A, Keyes E, Seymour CB, Mothersill CE, Schofield PN: Radiation-induced genomic instability is associated with DNA methylation changes in cultured human keratinocytes. Mutat Res 2006, 597(1-2):87-97.

19. Liehr JG: Genotoxicity of the steroidal oestrogens oestrone and oestradiol:possible mechanism of uterine and mammary cancer development. Hum Reprod Update 2001, 7(3):273-281.

20. Ansell PJ, Espinosa-Nicholas C, Curran EM, Judy BM, Philips BJ, Hannink M, Lubahn DB: In vitro and in vivo regulation of antioxidant response element-dependent gene expression by estrogens. Endocrinology 2004, 145(1):311-7.

21. Arbuckle TE: Are there sex and gender differences in acute exposure to cheicals $n$ the same setting? Environ Res 2006, 101:195-204.

22. Alworth LC, Howdesshell KL, Ruhlen RL, Day JK, Lubahn DB, Huang HM, Besch-Williford CL, Saal FS: Uterine responsiveness to estradiol and DNA methylation are altered by fetal exposure to diethylstilbestrol and methychlor in CD-1 M, Effects of low versus high doses. Toxicol App/ Pharmacol 2002, 183:10-22.

23. Rosenthal MD, Albrecht ED, Pepe GJ: Estrogen modulates developmentaly regulated gene expression in the fetal baboon liver. Endocrine 2004, 23(2-3):219-228.

24. Darbre PD: Environmental oestrogens, cosmetics and breast cancer. Best Practice \& Research. Clin Endocrinol \& Metabolism 2006, 20(1):121-143.

25. Barbieri RL, Gochberg J, Ryan KJ: Nicotine, cotinine, and anabasine inhibit aromatase in human trophoblast in vitro. J Clin Invest 1986, 77(6):1727-1733

26. Wang SL, Chang YC, Chao HR, Li CM, Li LA, Lin LY, Papke O: Body burdens of polychlorinated dibenzo-p-dioxins, dibenzofurans, and biphenyls and their relations to estrogen metabolism in pregnant women. EHP 2006, 114(5):740-745.

27. Hsieh M, Grantha E, Liu B, Macapagai R, Willingham E, Baskin LS: In utero exposure to benzophenone-2 causes hypospadias through an estrogen receptor dependent mechanisms. J Urol 2007, 178:1637-1642.

28. Birnbaum LS, Fenton S: Cancer and developmental exposure to endocrine disruptors. EHP 2003, 111(4):389-394.

29. Andersen HR, Bonefeld-Jorgensen EC, Nielsen F, Jarfeldt K, Jayatissa MN, Vinggaard AM: Estrogen effects in vitro and in vivo of the fungicide fenarimol. Toxicol Lett 2006, 163(2):142-152.

30. Hery C, Ferlay J, Boniol M, Autier P: Changes in breast cancer incidence and mortlaity in middle-aged and elderly women in 28 countries with Causcasian mjaroty populations. Annals of Oncology 2008, 19:1009-1018. 
31. Kovalchuk O, Tryndiyak P, Montgomery B, Boyko A, Kutanzi K, Zemp F, Warbritton AR, Latendresse JR, Kovalchuk I, Beland FA, Pogrybny IP: Estrogen-induced at breast carcinogenesis is characterized by alterations in DNA methylation, histone modifications and aberrant microRNA expression. Cell Cycle 2007, 6(16):2010-8.

32. Feigelson $\mathrm{HS}$, Henderson BE: Estrogens and breast cancer. Carcinogenesis 1996, 17(11):2279-84

33. Bernstein $J$, Langholz B, Haile RW, Bernstein L, Thomas DC, Stovall M, Malone KE, Lynch CF, Olsen JH, Anton-Culver H, Shore RE, Boice JD, Berkowitz GS, Gatti RA, Teitelbaum SL, Smith SA, Rosenstien BS, BorresenDale AL, Concannon P, Thompson WD: Study design:evaluating geneenvironment interactions in the etiology of breast cancer- the WECARE study. Breast Cancer Res 2004, 6:199-214.

34. Mitra AK, Faruque FS, Avis AL: Breast cancer and environmental risks: where is the link? J Environ Health 2004, 66(7):24-32

35. Zhang Y, Wise JP, Holford TR, Xie H, Boyle P, Hoar Zahm SH, Rusiecki J, Zou K, Zhang B, Zhu Y, Owens PH, Zheng T: Serum polychlorinated biphenyls $\mathrm{P}-4501 \mathrm{~A} 1$ polymorphisms, and risk of breast cancer in Connecticut women. Am J Epidemiol 2004, 160:1177-1183.

36. Nie J, Beyea J, Bonner MR, Han D, Vena JE, Rogerson P, Vito D, Muti P, Trevisan $M$, Edge SB, Freudenheim JL: Exposure to traffic emissions through life and risk of breast cancer: the western New Your exposure and breast cancer (WEB) study. Cancer Causes \& Control 2007, 18(9):947-955

37. Hilakivi-Clarke L, Cabanes A, de Assis S, Wang M, Khan G, Shoemaker WJ, Stevens RG: In utero alcohol exposure increases mammary tumorigenesis in rats. Brit J Cancer 2004, 90:2225-2231.

38. Warri A, Saarinen NM, Makela S, Hilakivi-Clarke L: The role of early life genistein exposures in modifying breast cancer risk. BJC 2008, 98:1485-1493.

39. Baik I, Becker PS, DeVito WJ, Lagiou P, Ballen K, Quesenberry PJ, Hsieh P. Stem cells and prenatal origin of breast cancer. Cancer Causes and Control 2004, 15:517-530

40. Brody JG, Rudel RA: Environmental pollutants and breast cancer. EHP 2003, 111(8):1007-19.

41. Brody JG, Aschengrau A, McKelvey W, Swartz CH, Kennedy T, Rudel RA: Breast cancer risk and drinking water contaminated by wastewater: a case control study. Environ Health 2006, 6:5-28.

42. Brody JG, Rudel RA, Michels KB, Moysich KB, Bernstein L, Attfiled KR, Gray S: Environmental pollutants, diet, physical activity, body size and breast cancer. Cancer (Suppl) 2007, 109(12):2627-2634.

43. Coutelle C, Hohn B, Benesova M, Oneta CM, Quattrochi P, Roth HJ, Schmidt-Gayk H, Schneeweiss A, Bastert G, Seitz HK: Risk factor in alcohol associated breast cancer: Alcohol dehydrogenase polymorphism and estrogens. Int J Oncology 2004, 25(4):1127-1132.

44. Fan S, Meng Q, Gao B, Grossman J, Yadegari M, Goldberg ID, Rosen EM: Alcohol stimulates estrogen receptor signaling in human breast cancer cell lines. Cancer Res 2000, 60:5635-5639.

45. Li XM, Ganmma D, Sato A: The experience of Japan as a clue to the etiology of breast and ovarian cancers: relatioship between death from both malignancies and dietary practices. Med Hypothesis 2003, 60(2):268-275.

46. Ganmaa D, Sato A: The possible role of female sex hormones in milk from cows in the development of breast, ovarian and corpus uteri cancers. Medical Hypothesis 2005, 65:1028-1037.

47. Ganmaa D, Wang PY, Qin LQ, Hoshi K, Sato A: Is milk repossible for male reproductive disorders. Med Hypothesis 2001, 57:510-514

48. Bennion BJ, Cosman M, Lightstone FC, Knize MG, Montgomery JL, Bennett LM, Felton JS, Kulp KS: PhIP carcinogenicity in breast cancer: computational and experimental evidence for competitive interactions with human estrogen receptor. Chem Res Toxicol 2005, 18:1528-1536.

49. Lauber SN, Gooderham NJ: The cooked meat-derived genotoxic carcinogen 2-amino-3-methylimidazol (4,5-b) pyridine has potent hormone-like activity: mechanistic support for a role in breast cancer. Cancer Res 2007, 67:9597-9602.

50. Ito N, Hasegawa R, Sano M, Tamano S, Esumi H, Takayama S, Sugimura T: A new colon and mammary carcinogen in cooked food 2-amino-1-methyl6-phenylimidazo (4,5b)pyridine (PhIP). Carcinogenesis 1991, 12:1503-1506.

51. Snyderwine EG: Mammary gland carcinogenesis by 2-amino-1-methyl-6phenylimidazo[4,5-b]pyridine in rats: possible mechanisms. Cancer Lett 1999, 143(2):211-5
52. Bonner MR, Han D, Nie J, Rogerson P, Vena JE, Muti P, Trevisan M, Edge SB, Freudenheim $J$ : Breast cancer risk and exposure in early life to polycyclic aromatic hydrocarbons using total suspended particulates as a proxy measure. Cancer Epidemiol Biomarkers Prev 2005, 14(1):53-60.

53. Coyle YM, Hynan LS, Euhus DM, Minhajuddin ATM: An ecological study of the association of environmental chemicals on breast cancer incidence in Texas. Breast Cancer Res Treatment 2005, 92:107-114

54. Ohayama K, Magai F, Tsuchiya Y: Certain styrene oligomers have proliferative activity on MCF-7 cells and binding affinity for human estrogen receptor alpha. EHP 2001, 109:699-703.

55. Ohyama Kl, Satoh K, Sakamoto Y, Ogata A, Nagai F: Effects of prenatal exposure to styrene trimers on genital organs and hormones in male rats. Exp Biol Med 2007, 232(2):301-308.

56. Kitamura S, Ohmegi M, Sanoh S, Sugihara K, Yoshihara S, Fujimoto N, Ohta S: Estrogenic activity of styrene oligomers after metabolic activation by rat liver microsomes. EHP 111(3):329-334.

57. Charlier CJ, Albert Al, Zhang L, Dubois NG, Plomteux GJ: Polychlorinated byphenyls contamination in women with breast cancer. Clin Chimaca Acta 2004, 347:177-181.

58. Moysich KB, Menezes RJ, Baker JA, Falkner KL: Environmental exposure to plychlorinated biphenyls and breast cancer risk. Rev Environ Health 2002 17(4):263-277.

59. Boffetta P: Human cancer from environmental pollutants: the epidemiological evidence. Mutat Res 2006, 608:157-162.

60. Stabile LP, Davis AL, Gubish CT, Hopkins TM, Luketich JD, Christie N: Human non-small cell lung tumors and cells derived from normal lung express both estrogen receptor alpha and beta and show biological response to estrogen. Cancer Res 2002, 62:2141-2150.

61. Fasco MJ, Hurteau GJ, Spivack SD: Gender dependent expression of alpha and beta estrogen receptors in human nontumor and tumor lung tissue. Mol Cell Endocrinol 2002, 188(1-2):125-140.

62. Stabile LP, Siefried JM: Sex and gender differences in lung cancer. J Gend Specif Med 2003, 6(1):37-48

63. Rivera MP: Lung cancer in women: the difference in epidemiology, biology and treatment outcomes. Expert Rev Resp Med 2009, 3(6):627-634

64. Olak J, Colson Y: Gender differences in lung cancer: have we really come a long way, baby? J Thorac Cardiovasc Surg 2004, 128:346-351.

65. Jemal A, Siegel R, Ward E: Cancer Statistics. Cancer J Clin 2006, 56:106.

66. Vineis $P$, Forastiere $F$, Hoek G, Lipsett M: Outdoor air pollution and cancer: recent epidemiologic evidence. Int J Cancer 2004, 111:647-652.

67. Whitrow MJ, Smith BJ, Pilotto LS, Pisaniello D, Nitschke M: Environmental exposure to carcinogens causinglung cancer: epidemiological evidence from the medical literature. Respirology 2003, 8:513-521.

68. Yang CY, Chiu HF, Chiu JF, Kao WY, Tsai SS, Lan SJ: Cancer mortality and residence near petrochemical industries in Taiwan. J Toxicol Environ Health 1997, 50:265-273.

69. Majidi M, Al-Wadel HA, Takahashi T, Schuller HM: Nongenomic beta estrogen receptor enchance beta1 adrenergic signaling induced by the nicotine-derived carcinogen 4-(methylnitrosamino)-1-(3-pyridyl)-1butanone in human small airway epithelial cells. Cancer Res 2007, 67:6863-6874.

70. Zhao Y, Wang S, Aunan K, Seip HM, Hao J: Air pollution and lung cancer risks in China- a meta-analysis. Sci Total Environ 2006, 366:500-513.

71. Ramanakumar AV, Parent ME, Siemiatycki J: Risk of lung cancer from residential heating and cooking fuels in Montreal, Canada. Am J Epidemiol 2007, 165:634-642.

72. Schwartz AG, Prysak GM, Murphy V, Lonardo F, Pass H, Schwartz J, Brooks S: Nuclear estrogen receptorbeta in lung cancer: expression and survival differences by sex. Imaging, Diagnosis, Prognosis 2005, 11(20):7280-7287.

73. Skov BG, Fischer BM, Pappot H: Oestrogen receptor beta over expression in males with non-small cell cancer is associated with beter survival. Lung Cancer 2008, 59(1):88-94.

74. $\mathrm{Xu} R$, Shu $Y$ : Estrogen and its signaling pathway in non-small cell lung cancer (NSCLC). J Najing Med Univ 2009, 23(4):217-223.

75. Beyer C, Küppers E, Karolczak M, Trotter A: Ontogenetic expression of estrogen and progesterone receptors in the mouse lung. Biol Neonate 2003, 84(1):59-63.

76. Oyama T, Sugio K, Isse T, Matsumoto A, Uramoto NH, Nozoe T, Morita M, Kagawa N, Muto TM, Yasumoto K, Kawamoto T: Expression of cytochrome P450 in non-small lung cancer. Frontiers Biosci 2008, 13:5787-5793. 
77. Slatore CG, Chien JW, Au DH, Satia JA, White E: Lung cancer and hormone replacement therapy:association in the vitamins and lifestyle study. $J$ Clin Oncol 2010, 28(9):1540-1546.

78. Matsuo K, Ito H, Yatabe $Y$, Hiraki A, Hirose K, Wakai K: Risk factors differ for non-small-cell lung cancer with and without EFGR mutation:assessment of smoking and sex by a case-control study in Japanese. Cancer Sci 2007, 98(1):96-101.

79. Samet JM: Environmental causes of lung cancer: what do we know in 2003? Chest 2004, 125:80-83.

80. Pauly JR, Slotkin TA: Maternal tobacco smoking, nicotine replacement and neurobeahavioural development. Acta Paediatrica 2008, 97(10):1331-1337.

81. Sarasin A, Schlumpf M, Muller M, Fleishmann I, Lauber ME, Lichtenstein Adrenal-mediated rather than direct effects of nicotine as a basis of altered sex steroid synthesis in fetal and neonatal rat. Reprod Toxicol 2003, 17(2):153-162.

82. Muggi ME, Elbert JO, Robertson C, Hurt RD: Waking a sleeping ginat: the tobacco industry's response to the Polonium-210 issue. Am J Pub Health 2008, 98(9):1643-1650.

83. Raymond-Whish S, Mayer LP, O'Neal T, Martinez A, Sellers MA, Christian PJ Marion SL, Begay C, Propper CR, Hoyer PB, Dyer CA: Drinking water with Uranium below the US EPA water standard causes estrogen receptordependent responses in female mice. EHP 2007, 115(12):1711-1716.

84. Beelen $R$, Hoek $G$, van den Brandt PA, Goldbohm RA, Fischer P, Schouten $L$, Jerrett $M$, Hughes $E$, Armstrong B, Brunekreef B: Long-term effects of traffic-related air pollution on mortality in a Ducth cohort (NLCS-AIR Study). EHP 2008, 116(2):196-202.

85. Laden F, Schwartz J, Speizer FE, Dockery DW: Reduction in fine particulate air pollution and mortality. Am J Respir Crit Care Med 2006, 173:667-672.

86. Misaki K, Suzuki M, Nakamura M, Handa H, lida M, Kato T, Matsui S, Matsuda T: Aryl hydrocarbon receptor and estrogen receptor ligand activity of organic exctracts from road dust and diesel exhaust particulates. Arch Environ Contam Toxicol 2008, 55:199-209.

87. Ssempebwa JC, Carpenter DO, Yilmaz B, DeCaprio AP, O'Hehir DJ, Arcaro KF: Waste crankcase oil: an environmental contaminant with potential to modulate estrogenic responses. J Toxicol Environ Health, Part A 2004, 67:1981-1094.

88. Van de Wiele T, Vanhaecke L, Boeckaert C, Peru K, Headly J, Verstraete W, Siciliano S: Human colon microbiota trasnform polycyclic aromatic hydrocarbons to estrogenic metablites. EHP 2005, 113:6-10.

89. Klein GP, Hodge EM, Diamond ML, Yip A, Dann T, Stern G, Denison MS, Harper PA: Gas-Phase ambient air contaminants exhibit significant dioxin-like and estrogen-like activity in vitro. EHP 2006, 114(5):697-703.

90. Cohen AJ: Outdoor air pollution and lung cancer. EHP 2000, 108:743-750

91. Parodi S, Baldi R, Benco C, Franchini M, Garrone E, Vercelli M, Pensa F, Puntoni R, Fontana V: Lung cancer mortality ina district of La Spezia (Italy) exposed to air pollution from industrial plants. Tumori 2004, 90:181-185

92. Shen J, Liu J, Xie Y, Diwan BA, Waalkes MP: Fetal onset of aberrant gene expression relevant to pulmonary carcinogenesis in lung adenocarcinoma development induced by the utero arsenic exposure. Toxicol Sci 2007, 95(2):313-320.

93. Tanaka Y, Sasaki M, Kaneuchi M, Fujimoto S, Dahiya R: Estrogen receptor alpha polymorhism and renal cell carcinoma- possible risk. Mol Cellular Endocrinol 2003, 202:109-116.

94. Moyad MA: Review of potential risk factors for kidney (renal cell) cancer. Semin Urol Oncol 2001, 19:280-293.

95. Ilyasova D, Schwartz GG: Cadmium and renal cancer. Toxicol Applied Pharmacol 2005, 207:179-186.

96. Hopenhayn-Rich C, Biggs ML, Smith AH: Lung and kidney cancer mortality associated with arsenic in drinking water in Cordoba, Argentina. Int J Epidemiol 1998, 27:561-569.

97. Søreide K, Aagnes B, Møller B, Westgaard A, Bray F: Epidemiology of pancreatic cancer in Norway: trends in incidence, basis of diagnosis and survival 1965-2007. Scand J Gastroenterol 2010, 45(1):82-92.

98. Luke C, Price T, Karapetis C, Singhai N, Roder D: Pancreatic cancer epidemiology and survival in an Australia population. Asian PaC $J$ cancer Prev 2009, 10(3):369-374.

99. Hariharan D, Saied A, Kocher HM: Analysis of mortality rates for pancreatic cancer across the world. HPB (Oxford) 2008, 10(1):58-62
100. Sauerland C, Engelking C, Wickham R, Pearlstone DB: Cancers of the pancreas and hepatobilliary system. Seminars in Oncol Nursing 2009, 25(1):76-92.

101. Lowenfels $A B$, Maisonneuve P: Epidemiology and risk factors for pancreatic cancer. Best Practice \& Res Clin Gastroenteol 2006, 20(2):197-209.

102. Konduri S, Schwartz RE: Estrogen receptor beta/alfa ratio predicts response of pancreatic cancer cells to estrogens and phytoestrogens. $J$ Surgical Res 2007, 140:55-66.

103. Andren-Sandberg A, Hoem D, Backman PL: Other risk factors for pancreatic cancer: hormonal aspects. Ann Oncol 1999, 10(Suppl 4):131-132.

104. Trushin N, Leder G, El Bayoumy K, Hoffmann D, Beger HG, Henne-Bruns D, Ramadani M, Prokopcyk B: The tobacco carcinogen NNK is stereoselectively reduced by human pancreatic microsomes and cytosols. Langenbecks Ach Surg 2008, 393:571-579.

105. Kummer V, Maskova J, Zraly Z, Matiasovic J, Faldyna M: Effect of postnatal exposure to benz(a)pyrene on the uterus of immature rats. Exp Toxicol Pathol 2007, 59(1):69-76.

106. Bogush TA, Dudko EA, Beme AA, Bogush EA, Polotskii BE, Tiuliandin SA, Davydov Ml: Estrogen receptor expression in tumors different from breast cancer. Antibiot Khimioter 2009, 54(7-8):41-49.

107. Ben-Porath I, Thomson MW, Carey VJ, Ge R, Bell GW, Regev A, Weinberg RA An embryonic stem cell-like gene expression signature in poorly differentiated aggressive human tumors. Nat Genet 2008, 40(5):499-507.

108. Batistatou A, Kyzas PA, Goussia A, Arkoumani E, Voulgaris S, Polyzoidis K, Agnantis NJ, Stefanou D: Estrogen receptor beta (ERbeta) protein expression correlates with BAG-1 and prognosis in brain glial tumours. $J$ Neurol 2006, 77(1):17-23.

109. Estrada M, Varshney A, Ehrilich BE: Elevated testosterone induces apoptosis in neuronal cells. Biol Chem 2006, 281(35):25492-25501.

110. Liu CC, Chen CC, Wu TN, Yang CY: Association of brain cancer with residential exposure to petrochemical air pollution in Taiwan. J Toxicol Environ Health, Part A 2008, 71:310-314.

111. Huyghe E, Plante P, Thonneau PF: Testicular cancer variations in time and sapce in Europe. Eur Urol 2007, 51:621-628.

112. Maffezzini M: TC incidence increasing: spread the word. European Urology 2007, 51:596-597.

113. Cavaco JE, Laurentino SS, Barros A, Sousa M, Socorro S: Estrogen receptors alpha and beta in human testis: both isoforms are expressed. Syst Biol Reprod Med 2009, 55(4):137-144.

114. Delbes G, Duquenne C, Szenker J, Taccon J, Habert R, Levacher C: Developmental changes in testicular sensitivity to estrogens through feral and neonatal life. Toxicol Sci 2007, 99(1):234-243.

115. Kaijser M, Akre O, Cnattinius S, Ekbom A: Maternal lung cancer and testicular cancer risk in the offspring. Cancer Epidemiol Biomarkers, Prevention 2003, 12:643-646.

116. Swerdlow AJ, Stiller CA, Wilson LM: Prenatal factors in the aetiology of testicular cancer: an epidemiological study of childhood testicular cancer deaths in Great Britain, 1953-73. J Epidemiol Community Health 1982, 36(2):96-101.

117. Smith LM, Cloak CC, Poland RE, Torday J, Ross MG: Prenatal nicotine increase testosterone levels in the fetus and females offspring. Nicotine Tob Res 2003, 5(3):369-374.

118. Storgaard L, Bonde JP, Olsen J: Male reproductive disorders in human and prenatal indicators of estrogen exposure. A review of published epidemiological studies. Reprod Toxicol 2006, 21(1):4-15.

119. McLachlan JA, Simpson E, Martin M: Endocrine disrupters and female reproductive health. Best Pract Res Clin Endocrinol Metab 2006, 20(1):63-75.

120. Drummond E, Fuller PJ: The importance of ERbeta signalling in the ovary $J$ Endocrinol 2010, 205(1):15-23.

121. Amram-Benamran ML, Cochet $S$, Petignat $P$, Sappino AP: Ovarian cancer screening: recommendations for clinical pratice. Rev Med Suisse 2010, 6(250):1066-1068.

122. Henson MC, Chedrese PJ: Endocrine disruption by cadmium, a common environmental toxicant with paradoxical effects on reproduction. Exp Biol Med 2004, 229:383-392

123. Grant WB: An ecologic study of dietary and solar ultraviolet-B links to breast carcinoma mortality rate. Cancer 2002, 94(1):272-281.

124. El-Zein R, Conforti-Froes N, Au WW: Interactions between genetic predisposition and environmental toxicants for development of lung cancer. Environ Mol Mutagenesis 1997, 30:196-204. 
125. Park SK, Yoo KY, Lee SJ, Kim SU, Ahn SH, Noh DY, Choe KJ, Strickland PT, Hirvonen A, Kang D: Alcohol consmtion, glutathione S-transferase M1 and T1 genetic polymorphysim and breast cancer risk. Pharmacogenetics 2000, 10:301-309.

126. Wadia PR, Vanderberg LN, Schaeberle CM, Rubin BS, Sonnenschein C, Soto AM: Perinatal bisphenol A exposure increases estrogen sensitivity of the mammary gland in diverse mouse strain. EHP 2007, 115(4):592-598.

127. Prins GS, Tang WY, Belmonte J, Ho SM: Developmental exposure to bisphenol A increases prostate cancer susceptibility in adult rats: epdegenetic mode of action is implicated. Fertility and Strerility 2008, 89(Suppl 1):41-42.

128. Miki Y, Suzuki T, Tazawa C, Blumberg B, Sasano H: Steroid and xenobiotic receptor (XR), cytochrome P450 3A4 and multidrug resistance gene 1 in human adult and fetal tissues. Mol Cellular Endocrinol 2005, 231:75-85.

doi:10.1186/1476-069X-11-S1-S8

Cite this article as: Fucic et al.: Environmental exposure to

xenoestrogens and oestrogen related cancers: reproductive system, breast, lung, kidney, pancreas, and brain. Environmental Health 201211

(Suppl 1):S8.

\section{Submit your next manuscript to BioMed Central} and take full advantage of:

- Convenient online submission

- Thorough peer review

- No space constraints or color figure charges

- Immediate publication on acceptance

- Inclusion in PubMed, CAS, Scopus and Google Scholar

- Research which is freely available for redistribution

Submit your manuscript at www.biomedcentral.com/submit
C Biomed Central 